\title{
CHLAMYDIA INFECTION IN ABORTED AND CLINICALLY HEALTHY EWES IN ASSIUT GOVERNORATE USING MICROSCOPICAL EXAMINATION AND ELISA
}

\author{
S.M. EL BERBAWY* and KHALED A.S. EL-KHABAZ ${ }^{* *}$ \\ *Animal Health Research Institute (AHRI), Assiut Lab \\ **Department of Animal Medicine (Infectious Diseases), faculty of Veterinary Medicine, Assiut University. \\ E-mail: khaledsayed 1970@yahoo.com
}

\begin{tabular}{|c|c|}
\hline & ABSTRACT \\
\hline $\begin{array}{l}\text { Received at: } 8 / 5 / 2014 \\
\text { Accepted: 5/6/2014 }\end{array}$ & $\begin{array}{l}\text { In } 3 \text { sheep breeding flocks in Assiut Governorate suffered from a problem of } \\
\text { abortion, after excluding Brucella infection using Rose Bengal and Buffered } \\
\text { acidified plate antigen test. Serum and endocervical swabs from } 92 \text { ewes ( } 72 \text { with } \\
\text { a history of abortion, } 20 \text { clinically healthy ewes) were examined using ELISA for } \\
\text { detection of antibodies against chlamydia and Giemsa staining for detection of } \\
\text { intracytoplasmic inclusion bodies in endocervical swabs. Only } 16 / 72(22.22 \%) \\
\text { and } 1 / 20(5 \%) \text { of previously aborted and clinically healthy ewes respectively were } \\
\text { found to be positive using ELISA, infection were more prevalent in ewes over 5-7 } \\
\text { years }(29.17 \%) \text { than in other age groups. No intracytoplasmic inclusion bodies } \\
\text { were detected in endocervical swabs. It could be concluded that chlamydia } \\
\text { infection was prevalent in ewes in Assiut Governorate; ELISA was a rapid } \\
\text { screening test for detection of infection in ewes while Giemsa staining was not a } \\
\text { reliable method in diagnosis of it. }\end{array}$ \\
\hline
\end{tabular}

Key words: Chlamydia, ELISA, endocervical swabs, Assiut, IgG immunoglobulins.

\section{INTRODUCTION}

Chlamydia are obligate intracellular pathogens that exist as two distinct forms during their life cycle that alternates between an extracellular infectious phase and an obligatory intracellular replicative phase that is not infectious (Martin and Aitken 2000). Elementary bodies (EBs) are metabolically inactive but environmentally stable and capable of infecting epithelial cells. Reticulate bodies (RBs) are incapable of infecting cells but are metabolically active and capable of replication. Following infection of eukaryotic cells, EBs rapidly transform to RBs which replicate to high numbers within an inclusion body, differentiate back to EBs, and then are released from the host cell by lysis (Hackstadt, 1999; Brunham and Rey - Ladino, 2005).

The family chalmydiaceae is divided into two genera, chlamydia and chlamydophila. Chlamydophila genus assimilates the current species, Chlamydia pecorum, Chlamydia pneumoniae and Chlamydia psittaci. Three new chlamydophila species are derived from chlamydia psittaci: Chlamydophila abortus, Chlamydophila caviae and Chlamydophila felis (Everett et al., 1999). All these species present various common antigens, the most important of which is the lipopolysaccharide antigen (LPS) (Brade et al., 1986).
Chlamydial abortion, known as enzootic abortion of ewes, causes serious reproductive wastage in many sheep - rearing areas of the world; abortion typically occurs in the last 2-3 weeks of pregnancy with the appearance of stillborn lambs and grossly inflamed placentas (Aitken and Longbottom, 2007). Enzootic abortion of ewes is caused by ovine strains of Chlamydia psittaci which have a predilection for placental tissues (Storz and Krauss, 1985). Placental and fetal infections with this gram - negative microorganism result in abortion or in the birth of stillborn, moribund, or weak lambs (Johnson, 1983). In severe outbreaks, up to one - third of the ewes may be affected; endemic disease in a flock may result in abortion rates of 1-5\% (Aitken, 1986) and (Apel et al., 1989). Plamer, (1990) mentioned that strains of C. psittaci were also associated with other diseases such as keratoconjunctivitis (Pink eye), arthritis and pneumonia. Human infection may be acquired from infected products of abortion or parturition or from carelessly handled laboratory cultures of the organism, with the effect that range from subclinical infection to acute influenza -like illness (OIE, 2012). Diagnosis of chlamydial abortion by isolation of the organism in embryonated chicken eggs or cell culture is often difficult and time consuming (Stroz and Krauss, 1985). In addition, bacterial contamination and unfavorable transport conditions further reduce the possibility of isolating this organism (Spencer and Johnson, 1983). There is need for more rapid and 
reliable techniques for direct (non-culture) detection of chlamydia in routine clinical specimens from sheep. Currently diagnostic tests for direct detection of C. psittaci in animal specimens are not commercially available (Souriau and Rodolakis, 1986). Enzyme immunoassay for $C$. trachomatis has been used to detect $C$. pisttaci in conjunctival swabs from cats (Wills et al., 1986). Very few ELISA, have been developed specifically for Chalmydia psittaci but many of those commercially available for C. trachomatis can be used because they detect the presence of common genus - specific antigen (lipopolysaccharide) shared both chlamydia species (Quinn et al., 1994). Indirect ELISA test is used to detect reactivity to genus specific antigen, or LPS, of chlamydial elementary or reticulate bodies. The indirect ELISA was efficient useful screening test for chlamydial abortion on the flock level, performed well, being more easier, sensitive and specific, it is of great help for epidemiological control of the disease (Longbottom et al., 2001; Buendia et al., 2001 and McCauley et al., 2007). Where the history of the flock and the character of lesions in aborted placenta suggest enzootic abortion, a diagnosis can be attempted by microscopic examination of smears made from affected chorionic villi or adjacent chorion, if placental material is not available, smears may be made from vaginal swabs of ewes that have aborted within the previous 24 hours (OIE, 2012). Several staining procedures are satisfactory, for example Giemsa, modified Ziehl - Neelsen Stains (Stamp et al., 1950). The present study aimed to investigate the prevalence of chlamydia infection in aborted and clinically healthy ewes also to compare between ELISA and direct smear stained by Giemsa in diagnosis of Chlamydia.

\section{MATERIALS}

\section{1) Animals}

This study were done upon 3 flocks of sheep (150 ewes) in Assiut Governorate, some of these ewes suffer from a problem of abortion during the last stage of pregnancy, from these flock, serum and endocervical swabs were taken as follows.

\section{2) Samples:}

\section{a- Serum samples:}

Serum samples were collected from 150 animals under complete aseptic condition. From these serum samples 92 were selected to be examined for presence of anti- chlamydia IgG using ELISA kit.

\section{b- Swabs:}

92 sterile endocervical swabs using cytobrush were taken for preparation of direct smear for Giemsa staining (Moncada et al., 1989)

\section{3) ELISA kit:}

- Chlamydia trachomatis IgG ELISA kit (DRG Diagnostics) DRG instruments $\mathrm{GmbH}$, Germany, FrauenbergsTraBe 18, D - 35039 Marburg. Lot No. $104 \mathrm{G} / \mathrm{K} 063$.

- Anti - ovine conjugate and the substrate were kindly supplied from Prof. Dr. Abdel-Rashied Ghaniem, chief researcher of bacteriology, Animal Health Research Institute - Dokki - Giza - Egypt.

\section{4) Reagents used in Giemsa stain:}

- Absolute methyl alcohol for fixation of smears.

- Ready to use Giemsa stain.

- Buffered water pH 7.2 prepared according (Monica, 1985).

\section{5) Antigens:}

Brucella Rose Bengal and Buffered acidified plate antigens (Sera and Vaccine Research Institute, Abbassya, Egypt).

\section{METHODS}

\section{1) Sampling:}

A. Serum sample collection according to (Black, 1997) and the data of animals like age, symptoms, and history were recorded.

B. Endocervical swabs according to (Moncada et al., 1989):

- The exocervix and the vagina were cleaned to remove excess mucus and any discharge or exudates; using a sterile cotton swabs.

- The cytobrush was inserted into the cervical canal, rotated for 15-30 sec., with enough pressure to obtain cells from the lining mucous membrane. The swab was rolled to a clean sterile glass slide over a $10 \mathrm{~mm}$ defined area and leave it dried.

\section{2) Procedures:}

- Buffered acidified plate antigen (BAPA) test and Rose Begnal Plate antigen test (RBPT) were performed as described by Alton et al. (1988).

All the 150 serum samples were screened for presence of brucellosis using the two tests.

- ELISA

The test was done upon 92 tested serum samples in addition to one control positive, one control negative and 2 cut off samples. It performed according to the instruction of the producer and the reading was done using semi-automated ELISA reader.

- Staining technique:

According to (Carter,1984) in which the direct smears were fixed by Absolute methyl alcohol for 5 minutes then stained with diluted 10\% Giemsa stain (Freshly prepared) for 20 minutes. The dried slides were examined microscopically under oil immersion lens (at $1000 \mathrm{X}$ ). 
RESULTS

All the 150 serum samples were negative for brucellosis by RBPT and BAPA tests.

Table 1: Results of ELISA for detection of IgG against chlamydial species in sera of tested ewes.

\begin{tabular}{|c|c|c|c|c|c|}
\hline \multirow{2}{*}{ Animal } & \multirow{2}{*}{ Total No. } & \multicolumn{2}{|c|}{ Positive } & \multicolumn{2}{|c|}{ Negative } \\
\hline & & No. & $\%$ & No. & $\%$ \\
\hline Previously aborted & 72 & 16 & 22.22 & 56 & 77.78 \\
\hline Clinically healthy & 20 & 1 & 5 & 19 & 95 \\
\hline Total & 92 & 17 & 18.48 & 75 & 81.52 \\
\hline
\end{tabular}

Table 2: Results of ELISA for detection of IgG against chlamydial species in sera of tested ewes of different age group.

\begin{tabular}{cccccc}
\hline & & \multicolumn{3}{c}{ Positive } & \multicolumn{2}{c}{ Negative } \\
\cline { 3 - 6 } Age group & No. of ewes & No. & $\%$ & No. & $\%$ \\
\cline { 3 - 6 } & & 40 & 13.33 & 26 & 86.66 \\
\hline$>3-5 \mathrm{y}$ & 38 & 6 & 15.79 & 32 & 70.83 \\
\hline$>5-7 \mathrm{y}$ & 24 & 7 & 29.17 & 17 & 81.52 \\
\hline
\end{tabular}

Table 3: Results of direct smear stained with Giemsa:

\begin{tabular}{|c|c|c|c|c|c|}
\hline \multirow{2}{*}{ Animal } & \multirow{2}{*}{$\begin{array}{c}\text { Total } \\
\text { No. }\end{array}$} & \multicolumn{2}{|c|}{ Positive } & \multicolumn{2}{|c|}{ Negative } \\
\hline & & No. & $\%$ & No. & $\%$ \\
\hline Previously aborted & 72 & 0 & 0.00 & 72 & 100 \\
\hline Clinically healthy & 20 & 0 & 0.00 & 20 & 100 \\
\hline
\end{tabular}

\section{DISCUSSION}

Chlamydia can adapt many host species and consequently is of direct public health concern. Also chlamydia has a novel route of transmission (Ozbek et al., 2008). It is difficult to culture chlamydia; this necessitates special culture media, special handing, rapid transport to laboratory, and rapid inoculation of cultures (Smith et al., 1982). Thus, culture is not generally available, and if available, it is too expensive for routine use. The clinical findings and macroscopic lesions of Chlamydia infections are not pathogonomic (Kalender et al., 2013) so this study was attempted to rapid and reliable diagnosis of chlamydia in examined sheep.

Result illustrated in table (1) proved that IgG against chlamydial species were detected by indirect ELISA in $(18.48 \%) 17$ out of 92 examined ewes. These results higher than that obtained by Markey et al. 
(1993) they found that $11.24 \%$ of serum samples from different farms of sheep have a significant level of antibodies titers against chlamydophila abortus by using ELISA. But the present obtained results were lower than that obtained by (Mariam, 2005), who reported $\operatorname{IgM}$ against chlamydial species in 78 out of $302(25.8 \%)$ of ovine serum using ELISA and that obtained by Hala et al. (2006) who reported antibodies in $(33.33 \%)$ in ewes using ELISA, also IgG chlamydial antibodies detected by Apel et al. (1989) in 277 (30\%) of 922 ovine sera. Huang et al. (2013) detected antibodies against Chlamydia in 95 of 455 (20.9\%) sheep in China. The variances of these results may be attributed to regional variation, husbandry, management practice and diagnostic techniques used.

The results of ELISA in the serum samples of clinically health ewes, as showing in table (1), showing that one ewes out of (20) cases with a percentage of $(5 \%)$ was serologically positive, while $16(22.22 \%)$ out of 72 ewes with a previous history of abortion was serologically positive. This results agree with Apel et al. (1989) who recorded that sera from herds showing symptoms indicative for chlamydial infections have significantly higher antibody rates (39\% in sheep) than sera from herds without health problems (24\%).

The highest prevalence $(29.17 \%)$ of chlamydia infection among examined ewes was detected within age $>5-7$ years as shown in table (2), and this agree with the results of (Clarkson and Philips, 1997) as they found that the prevalence rate of chlamydia infection increased among aged sheep than lambs. While Jerant - Patić et al. (2009) stated that chlamydia infection was equally distributed in all age groups.

Results illustrated in table (3) proved that No inclusion bodies were detected in 92 direct smears stained with Giemsa. While (Mariam, 2005), detected inclusion in $(3.3 \%) 10$ out of 302 aborted ewes using direct smear stained with Giemsa. Also elementary bodies were seen in 26 of 176 stained smears from placental or fetal specimens (Abilgasanov, 1982). However (Brown and Newman, 1989) mentioned that stained smear technique was low in its sensitivity because it identifies only elementary bodies and negative results don't exclude the presence of chlamydiae. Mandeep and Andersen, (2000) reported that smears made from cervical swabs of ewes that aborted within the previous 24 hours contain fewer organisms than placental smears, this explain the negativity of the present result in which the samples were taken from endocervix not from placenta and from ewes aborted after relatively a long time not from recent abortion.
On other hand Quinn et al. (1994); Schachter et al. (1995) and Black, (1997) they revealed that direct cytologic testing by Giemsa stain was rapid for detecting chlamydial conjunctivities in new born, and in smears prepared from conjunctival scrapings particularly those from cats with feline pneumonitis, but with poor sensitivity in diagnosis of other chlamydial infections and were not commonly used. Lin et al. (1999) stated that the positive result using Giemsa staining was difficult to be recognized. Detection of inclusion bodies by microscopy is not adaptable for a large scale (Wang et al., 2007).

It can be concluded that chlamydia infection was prevalent in ewes in Assiut Governorate and it seemed that it is one of important abortificient diseases in sheep, large scale studies are needed to detect the accurate prevalence rate of animal chlamydiosis in Assiut. Indirect Enzyme Linked Immunoassay (indirect ELISA) was easily to perform and can be used as a rapid screening test for detection of chlamydia in infected ewes or clinically healthy one, and the endocervical direct smear stained with Giemsa is not a reliable method in diagnosis of chlamydia in ewes.

\section{ACKNOWLEDGMENT}

The authors greatly appreciate the great help of Prof Dr. Abdel-Rashied Ghaniem in his kindly supplying the anti-ovine conjugate and the substrate.

\section{REFERENCES}

Abilgasanov, M.M. (1982): Chlamydial abortion in cows, buffaloes and Zebu. Veterinariya, Moscow, USSR; No (12) 57-58.

Aitken, I.D. and Longbottom, D. (2007): Chlamydial abortion. In diseases of sheep fourth edition. Aitken I. D., ed. Blackwell scientific lid., Oxford, U K, 105-112.

Aitken, I.D. (1986): Chlamydial abortion on sheep. In pract 8: 236-237.

Alton, G.G.; Jones, L.M.; Angus, R.D. and Verger, J.M. (1988): Techniques for brucellosis laboratory institute. National de la Recherché Agronomique, 174 eve de I, universite, 75007.

Apel, J.; Hübschle, O.J. and Krauss, H. (1989): Seroprevalence of chlamydia psittaci - specific antibodies in small stock in Namibia epidemiological study with an enzyme - linked immunosorbent assay (ELISA). Zentralbl veterinarmed B. 36: 447-458.

Black, C.M. (1997): Current method of laboratory diagnosis of chlamydia trachomatis infections. Clin. Mirco. Rev.; 10: 160-184.

Brunham, R.C. and Rey-Landino, J. (2005): Immunology of chlamydia infection implication for a chlamydia trachomatis vaccine. Nat Rev. Immunol. 5 (2), 149. 
Brade, L.; Schramek, S; Schade, U; Brade, $H$. (1986): Chemical, biological and immunochemical properties of the chlamydia psittaci lipopolysaccharide. Infect. Immun. 54, 568-574.

Brown, P.A. and Newman, J.A. (1989): Methods of chlamydial antigen detection. JAVMA. Vol. 195, (11): 1567-1576.

Buendia, A.J.; Cuello, F; Rio, L. and Caro, M. (2001): Field evaluation of a new commercially available. ELISA based on a recombinant antigen for diagnosing chlamydia Psittaci infection. Vet. Microbiol. 78: 229-239.

Carter, G.R. (1984): Diagnostic procedures in veterinary Bacteriology and Mycology, $4^{\text {th }}$ ed. Charles C Thomas. Publisher. USA. pp 482.

Clarkson, M.J. and Philips, H.L. (1997): Isolation of faecal chlamydia from sheep in Britain and their characterization by cultural properties. Vet. J., 153 (3): 307-311.

Everett, K.D.; Bush, R.M. and Andersen, A.A. (1999): Emended description of the order chlamydiales, proposal of parachlaymdiaceae fam. nov., each containing one monotypic genus, revised toxonomy of the family chlamydiaceac, including a new genus and five new species, and standards for the identification of organisms. Int. J. Syst. Bacteriol 49, 415-440.

Hackstadt, T. (1999): Cell Biology. In stephens. R. S. (Ed), chlamydia. Intracellular Biology. Pathogenesis and immunity ASM press. Washington. D. C. pp. 101.

Hala, Abu Shady. M.; Mousa, H.A.; El-beih, F.M. and Allam, S.A. (2006): Detection of Chlamydophila abortus as an important Etiology for Enzootic Abortion by cell cytology, serology, and Polymerase Chain Reaction. J. Egypt Vet. Med Asso. 66 (1): 37-46.

Huang, S.Y.; Wu, S.M.; Xu, M.J.; Zhou, D.H.; Donba, C.; Gong, G. and Zhu, X.G. (2013): First record of Chlamydia abortus seroprevalence in Tibetan sheep in Tibet, China. Small Ruminant Research. 112 (1-3). 243-245.

Jerant-Patić, V.; Milosević, $V$. and Kozarer, $G$. (2009): Chlamydia trachomatis in women. Med. Pregl. Jan-Feb., 62 (1-2) 7-12.

Johnson, F.W.A. (1983): Chlamydiosis. Br. Vet. J. $139-93-101$

Kalender, H.; Kiliç, A.; Hröksüz, H.; Muz, A.; Kiliç, $\ddot{U}$. and Taşdemir, B. (2013): Identification of chlamydophila abortus in aborting ewes and goats in Eastern Turkey. Revue Méd. Vét, 164 (6): 295-301.

Lin, J.; Li, Y.; Zhang, J.; Feng, G.; Zhang, P.; Zheng, $H$. and Zheng, J. (1999): Rapid diagnosis of chlamydial conjunctivitis in laboratory. Yan. Ke. Xue. Bao. Sep, 15 (3): 191-194.
Longbottom, D.; Psarrou, E. and Livingstone, M. (2001): Diagnosis of ovine enzootic abortion using an indirect ELISA based on a recombinant protein fragment of the polymorphic outer membrane protein of chlamydophilia abortus (C. psittaci). FEMS Microb. Letters, 195: 157-161.

Mandeep, Sh. and Andersen, A.A. (2000): Isolation and growth of chlamydia in cell culture, Indian journal of Animal science, 70 (11): 1127-1128.

Mariam, F.M. (2005): Chlamydiosis. Ph.D.Thesis Microbiology department. Fac. Vet. Med. Assiut. Un. Egypt. pp.161.

Markay, B.K.; McNulty, M.S. and Todd, D. (1993): Comparison of serological tests for the diagnosis of chlamydia psittaci infection of sheep. Veterinary Microbiology, 36: 233-252.

Martin, W.B. and Aitken, I.D. (2000): Chlamydial abortion. In disease of sheep. Third edition. Black well science KK. Japan. Chapter 12: 81-86.

McCauley, L.; Lancaster, M.; Young, P.; Bulter, K. and Ainswarth, C. (2007): Comparison of ELISA and CFT assay for chlmydophila abortus antibodies in ovine sera. Aust. Vet. J., 85 (8): 325-328.

Moncada, J.; Schachter, J.; Shipp, M.; Bolan, G. and Wilber, J. (1989): Cytobrush in collection of cervical specimens for Detection of Chlamydia trachomatis, J. of clinical Microbiology, 27 (8): 1863-1866.

Monica, C. (1985): Medical laboratory. Manual for tropical countries. Vol. 11 co-published by Tropical Health Technology and Butter Worths, 436-444.

OIE (2012): Enzootic abortion of ewes (Ovine chlamydiosis). Chapter 2. 7.7.

Ozbek, A.; Ozbek, E.; Kalkan, Y.; Temur, A. and Küeükkalem, O.F. (2008): [can Chlamydia trachomatis Human biovars cause abortion in cattle? An immuohistochemical study on a new host. Pathogen relationship]. Mikrobiyol. Bul., 42 (4): 599-605.

Plamer, N.C. (1990): Chlamydia abortion of sheep and goats Vet. Lab. Services Branch, Guelph Ministry of Agriculture and food office Ontario - Canada. Copyright 2003 Gueen's Printer forontario., last updated Feb, 27, 2003.

Quinn, P.J.; Carter, M.E.; Markey, B.K. and Carter, G.R. (1994): The chlamydiales (order), 310-314.

Schachter, J.; Moncada, J.; Whidden, R.; Shaw, H.; Bolan, G.; Burczak, J.D. and Lee, H.H. (1995): Non invasive tests for diagnosis of Chlamydia trachomtis infection : application of ligase chain reaction to first - catch urine specimens of women, j. Infect Dis, 172: 1411-1414. 
Smith, T.F.; Brown, D.S. and Weed, L.A. (1982): Diagnosis of chlamydia trachomatis infections by cell cultures and serology. Lab. Med., 13: 92-100.

Souriau, A. and Rodolakis, A. (1986): Rapid detection of chlamydia psittaci in vaginal swabs of aborted ewes and goats by enzyme linked immunosorbent assay (ELISA). Vet. Microbiol. 11: 251-259.

Spencer, WN. and Johnson, FWA. (1983): Simple transport medium for the isolation of chalmydia psittaci from clinical material. Vet. Rec. 113: 535-536.

Stamp, J.T.; McEwen, A.D.; Watt, J.A.A and Wisbet, D.I. (1950): Enzootic abortion in ewes. I. Transmission of the disease, Vet. Rec. 62, 251-254.
Stroz, J. and Krauss, H. (1985): Chlamydial infection and diseases of animals. In: Handbook of bacterial infections in animals, ed. Blobel $\mathrm{H}$, Schliesser T, vol. v, pp. 447-651. Fischer verlag. Jena, FRG.

Wang, S.; Indrawati, L.; Wooters, M.; Caro-Aguilar, I.; Field, J.; Kaufhold, R.; Payne, A.; Caulifield, M.J.; Smith, J.G. and Heinrichs, J.H. (2007): A novel automated method for enumeration of chlamydia trachomatis inclusion forming units, journal of immunological Methods 324: 84-91.

Wills, J.M.; Millard, W.G. and Howard, P.E. (1986): Evaluation of a monoclonal antibody based ELISA for detection of feline chlamydia psittaci. Vet. Res. 119: 418-420.

الإصابة بميكروب الكلاميديا فى إناث الأغنام المجهضة و السليمة ظاهرياً فى محافظة أسيوط باستخدام الفحص الميكروسكوبى والإليزا

سعد محروس البرباوي ، خالد احمد سبي الخباز

E-mail: khaledsayed_1970@yahoo.com

أجريت هذه الدر اسة على ثلاثة قطعان ( •(1) رأس من الأغنام بمحافظة أسيوط تعانى من مشكلة الإجهاض وقد نم تجميع عينات

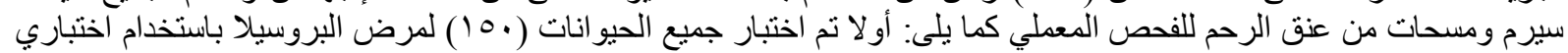

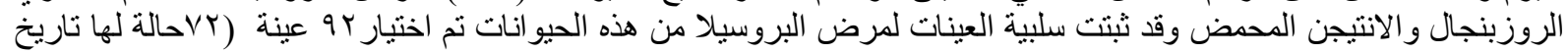

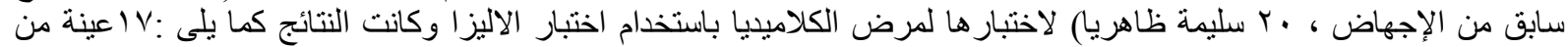

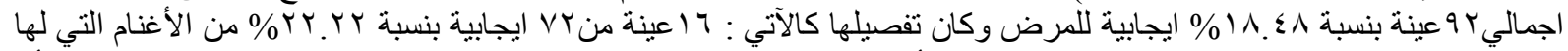

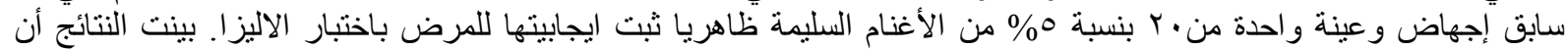

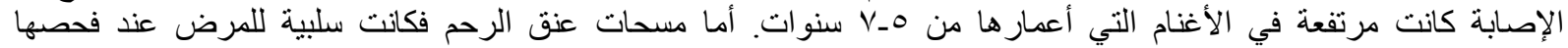
ميكروسكوبيا بعد عمل شرائح منها وصبغنها بالجيمسا. وقد تم مناقتة النتائج تفصيليا بالبحث. 